\title{
Vocationalization of Secondary Schools: Implementation Reality or Fallacy?
}

\author{
By \\ ${ }^{1}$ Leona Mandiudza, ${ }^{1}$ Winnet Chindedza, ${ }^{1}$ Jeriphanos Makaye
}

\begin{abstract}
The study attempted to evaluate one of the recommendations of the Nziramasanga Commission of Inquiry into Education and Training viz the vocationalisation of the Secondary Schools curriculum. The study has established that vocationalisation in most Secondary Schools is mere window dressing, as evidenced by poor to non implementation of the policy directives in most schools due to lack of infrastructure, human resources and equipment. The interviews and observations check list done showed that the implementation of vocational subjects in secondary schools is an uphill struggle. The study also revealed that the negative perception of technical subjects perpetuated from the colonial era still prevails and affects negatively the implementation of these subjects. To make matters worse on the implementation, teachers, pupils and parents still hold the idea that pupils who do technical subjects are not academically talented. Even teachers themselves have prestige in teaching academic subjects. Teachers who teach technical subjects are looked down upon just as the subjects they teach. In the end these subjects lose popularity since teachers who are able to teach them develop an inferiority complex. The study recommends a re-education of the whole nation on the value of vocational and technical subjects. Although there are policies guiding the implementation of technical and vocational subjects there is need of strict stringent policy adherence by all stakeholders.
\end{abstract}

Key Words: vocationalisation of secondary schools; school curriculum; technical subjects; vocational subjects

\section{Introduction and Background}

Commissions of Inquiry into educational matters in general and the curriculum in particular, especially vocationalising, have a long history in Zimbabwe. It has been observed that if these commissions' recommendations were implemented, the present education system would be quite different. A brief account of these commissions would help explain the point.

${ }^{1}$ Great Zimbabwe University Lecturers

Faculty of Education, Department of Curriculum Studies 
The Frank Tate commission of 1929 called for a compulsory manual and practical curriculum, a policy which remained in practice in European schools until 1980. Six years later in 1935, the Fox Commission opposed a mere academic secondary curriculum with less practical skills for European children and recommended a curriculum with more than one track of learning. The Kerr Commission of 1952, also recognized the need to give skills to African children. The recommendation was however given a lukewarm treatment. The judges Commission of 1963 recommended Vocational and Technical Education for African schools but the recommendation was diluted into F2 secondary school system in 1966. This reform introduced a practical subject curriculum which ran parallel with the academic and more prestigious F1 system. This system was responsible for the development of negative attitudes towards practical subjects. Consequently, the F2 schools were phased out at independence and these schools were converted into conventional F1 Schools. The golden opportunity to develop Vocational and Technical education using resources that had been put in place was abandoned. The Lewis Taylor Committee (1974) also recommended that imparting of skills be part of the general education for all.

The recommendations by the pre-independence commissions and committee were not implemented except in schools for white children. At the attainment of independence in 1980, it was therefore, necessary to review the education system but no commission was set up. Policy makers set up task forces as a strategy to improve education but these did not take ideas from the general populace. It was at this time that the Zimbabwean government embarked on reforms which necessitated the institution of the democratisation of education and training. The policy ushered in expansive and extensive provision of education which necessitated a comprehensive review of the system to check on its relevancy. This then led to the setting up of the Nziramasanga Presidential Commission of Inquiry into Education and Training [ CIET] in January 1998.

The commission among other Terms of Reference (TOR) was to inquire into and report upon the inherited education system as to relevance, quality and orientation in a rapidly changing socio-economic environment.

Whilst inquiring into this broad issue from the Zimbabwean people, the commission noted that:

- the current secondary education was academically good but did not cater for the majority of the students, neither did it prepare them for the skills needed in the world of work.

- people wondered what the use of an 'O' or 'A' Level certificate was if it did not prepare students for work. 
- our secondary education was found to be a waste of time for the majority of our students as it handled them as if they all would end up doing ' $A$ ' Level and university studies.

- the country was still giving, to all secondary students, an old British-type education which captains of commerce and industry thought created a missing link between the school system and employment sector. Chinoona (2006) also noted that colleges and the employment sector could absorb not more than $20 \%$ of the school leavers since the majority of them lacked the necessary skills.

- this resulted in frustration and a sense of failure in students as even some who got five 'O' Levels got equally frustrated because they had no marketable skills. There will not be any employment for them yet the pupils are not educated in commercial practice for self-employment and self reliance.

- the secondary education was too academic and examination driven. The concern for passing examinations took the centre stage to the prejudice of all other forms of useful learning.

- schools, especially in rural areas were generally under resourced .

- there was an observed absence of inspectors in schools.

Having established the above facts, the commission made some recommendations to redress the shortcomings. Of interest to this paper are recommendations that proposed a genuine shift from an education that is too academic and examination driven to a one that emphasizes experiential learning and development of desirable traits and competencies in students.

The commission recommended the vocationalisation of the curriculum to cater for the various talents and interests of children thereby making it relevant to the needs of the children and the nation's aspirations and developmental needs. The nation was to adopt a Two- Pathway education system into which students were to be channeled after Form 2.The commission also recommended that:

- students who would follow the vocational and technical route be required to undergo a designated period of attachment in order to have hands-on experience.

- the vocational and technical education should be offered through curricula designed by stakeholders who include commerce and industry and relevant professional boards.

It is against this background that this paper seeks to evaluate how far the above recommendations have been implemented. Possible solutions to challenges that might have been encountered will also be suggested. 


\section{Statement of the Problem}

Recommendations of commissions of inquiry into education are, in most cases, not seriously taken. No matter how revolutionary the recommendations may be, they are not implemented in the positive educational and professional spirit in which they are recommended. Some important recommendations of previous commissions which did not see the light of the day, would have made the state of education better than what it is, if only they had been implemented. The study is therefore guided by the following questions.

1. What hinders the implementation of reforms, especially the Two- pathway system in Zimbabwe?

2. Are the relevant educational policies in place to guide and support the implementation process?

3. Are schools/ institutions of learning ready in terms of resources, both human and material to be able to implement the recommendations?

To address these questions and other issues the discussion takes a curriculum evaluation approach.

\subsection{Theoretical Framework}

This paper is based on the recommendations of the Nziramasanga Commission of inquiry into Education and Training to change the curriculum to suit the prevailing socio-economic conditions of the country. No curriculum remains relevant and perfect for all ages. It must keep changing to address new needs that emerge as society changes (Shiundu and Omulando 1992). There is need, therefore, to subject the curriculum to some evaluation and analysis. The evaluation done must be seen as a phase in the process of constructing and reconstructing curricula to make it relevant (Oliva 1992). The information got from the evaluation and analysis is necessary in order to give feedback to planners so that they can make some recommendations having reached some conclusions. The paper will therefore attempt an evaluation of the current school curriculum versus the recommendations of the commission to assess how far they have been implemented.

\section{Sources and Generation of Data}

The study was carried out to establish the extent to which the Nziramasanga Commission of Inquiry into Education and Training's recommendation to have a Two-Pathway education system has been incorporated in the school system. The school system encompasses all stake holders such as Heads, Teachers, pupils, education system and instructional materials. The population of the study comprised of forty-three (43) secondary schools in 
Masvingo District of Masvingo Province, 5348 Form 4 year 2010 students in the district and Vocational and Technical subject teachers together with the Heads or Deputy Heads of the selected schools. It also included the secondary school inspectors based at the provincial offices. Ministry of Education, Sport, Arts and Culture policy documents and Directors' circulars were also scrutinised to evaluate efforts made to implement the recommended curriculum.

\section{Data Analysis \\ 4.1 Ministry Initiatives}

As the need to relate the curriculum to the world of work came to naught when the F2 System could not survive the political storm at Independence, Ministry had to engage in some reforms to compensate for that. The Nziramasanga Commission's Findings triggered the Ministry into taking action and a series of circulars were issues directing schools to implement the recommendations i.e. vocationalisation of the curricula through the Two-Pathway structure.

Firstly there was the Secretary Circular Number 2 of 2001. This circular directed all schools to offer at least one technical/ vocational subject to all pupils at Ordinary level as per the commission recommendations. This policy circular was, unfortunately, cancelled and replaced by the Secretary's circular number 3 of 2002 which was on Curriculum Policy for Primary and Secondary Schools. This circular favoured academic subjects as it reversed the gains of circular 2 of 2001 by making vocational and technical subjects optional. This was a result of the change in Secretaries of education. In 2002, we can safely say there was no policy guiding the proper implementation of vocational subjects. Schools were at liberty to choose what they wanted to do i.e. whether to include them as part of their curriculum or not. Most schools opted to have very few students doing the subjects due to other reasons especially lack of resources.

In 2006, when it was realised that academic education unrealistically exaggerated the educational and occupational aspirations of the school graduates, creating excessive demand for university education and highly valued jobs, (Psacharopolous and Loxley (1985) circulars were generated by the Ministry redirecting all schools to introduce vocational education.

In January 2006, Director's circular number 3 of 2006 was generated. This was on Policy Guidelines on the implementation of the Two-Pathway Education Structure in Schools. The Director clearly stated that this was in line with the Nziramasanga Commission's recommendations. The Two- Pathway system was meant to give the learners a broad curriculum at Form 1 and 2 levels which included Sciences, Mathematics, Humanities, Computers, Languages, Business/ Commercial subjects and Technical/Vocational subjects. After Form 2 students would then be channelled to different pathways according to their abilities and 
interests. From the Director's point of view, there was no doubt that the quality and relevance of education in the country was to a large measure, going to depend on the successful implementation of the Two-Pathway education structure.

The Director's circular was also supported by the Permanent Secretary's Policy Circular Number 77 of 2006 which clearly spelt out that:

All schools must implement the Two-Pathway Education Structure in Zimbabwe in line with the recommendations of the 1999 Presidential Commission of Inquiry into Education and Training. (CIET).

The Commission had successfully managed to make the Ministry of Education aware of the need to offer vocational education but, it seems, its non implementation betrayed everyone. This is evidenced by the recurrence of calls to implement the Two-Pathway by the Ministry through the Principal Director's Circular Number 33 of 2010. This circular was on "Policy Guidelines for offering Technical and Vocational Education". This was again echoed by another Director's circular number 45 of 2006 referenced "Assistance to Government and Mission Boarding Schools for Production and Skills Development Purposes," an approach which the directors said was in line with the 1999 Presidential Commission of Inquiry into Education and Training (CIET) Guidelines on this circular were meant to enable Government Boarding Schools to access resources. This however never materialised in most schools.

For any curriculum reform to make an impact, no matter how appropriate or valued it may be, it must be implemented (Ornstein and Hunkins 1993). These authors go further to asset that most new programs do nothing more than gather dust on shelves because they get blunted at classroom doors. This is the situation with the Two-Pathway system because from 1999 to date, calls are still being made to implement the Commission's recommendations. The HERALD of Thursday 29 July 2010 shows that the curriculum is still in need of reform. The paper quoted the Minister of Education, Sport, Arts and Culture, Senator David Coltart, lamenting the present state of the curriculum saying "the current curriculum has not been that comprehensive as it was updated over two decades ago". The article was entitled "SCHOOL CURRICULUM OVERHAUL ON CARDS". This is a clear testimony that the recommendations of the Commission had not been implemented.

The recurrences of calls to vocationalise the curriculum and repetition of circulars on guidelines on how the Two-Pathway should be implemented, shows that the most problematic thing of the education system is institutionalising reforms. The most pressing problem is to develop strategies whereby schools are transformed to be able to solve problems and be ready to accommodate reforms. 


\subsection{Pupils}

Pupils were given a questionnaire to respond to on how they came to be in their respective classes at Form 3 level. Their responses showed that no continuous assessment is being done at Form one and two level which must be the base for channelling these pupils to different pathways as recommended by the commission and also as directed by the Director's circular 9 of 2007. Subjects are just imposed on pupils instead of allowing them to make choices that suit their conditions.

The education system has to take into consideration the many psychological and sociological factors that have an influence on shaping the pupils' carrier choices. Schools have therefore to form and direct occupational preferences for pupils.

Some pupils revealed that they were streamed according to how they had fared in Mathematics, English and Science internal examinations at Form two level. The Two-Pathway structure, meant to cater for different abilities as per Secretary's Circular number 14 of 2004 is not being adhered to. The use of academic subjects to channel pupils into Form 3 classes is a violation of the Director's Circular Number 9 of 2007 which states that:

Continuous assessment from primary through to lower secondary school level should be taken seriously if we are to provide relevant education to our learners. Appropriate continuous assessment will also ensure that leaners will be channelled into suitable pathways in their education beyond Form 2.

The Commission had done well in recommending that the Zimbabwe Junior Certificate Examinations be abolished in favour of continuous assessment but what the schools are doing clearly shows that society's shared values may not represent the reality in schools (Dalton 1988). If adhered to, the recommendation was going to see our learners being channelled to their Form three classes according to their abilities, thereby developing in them desirable attitudes and skills that will lead to the moral, social and economic development of our nation. A challenge, however, arises when pupils are not decided on what they really want to do. They may have excelled in particular vocational subjects at Form 2 level but later develop interest in different areas. Most of these pupils are still in their tentative choice period and are not yet serious about carrier choices. This will mean that the vocational subjects must then be taught like academic subjects in the curriculum, and not for the purpose of making pupils acquire certain skills. The poor facilities and shortage of resources in the mainstream secondary schools as compared to specialist centres also support this idea.

Disparity between what is expected and the reality constitute a major barrier to innovation. Teacher's perceptions are therefore central to an understanding of curriculum development and change otherwise they may super impose their own very different interpretations of educational philosophies. 


\subsection{Teachers}

Teachers have the influence of the colonial error where the vocational subjects were seen as unimportant and used as a way of oppressing the Africans. This echoes Woodhall (1981)'s perception that the success of vocational education is depended on its economic value which lies not only on its ability to impart productive skills but also in its ability to influence attitudes. Teachers must be able to see the economic value of the vocational subjects in order to change their attitudes towards them and be able to take personality traits that influence carrier choices into consideration when helping pupils to make choices about the subjects they want to do. Vocational and technical subject teachers interviewed echoed what their students had said i.e. channelled to their respective classes according to how they had fared in academic subjects chosen by administration at Form 2 level.

\subsection{Heads}

It was sad to note that most heads interviewed did not know of the existence of circulars directing them to offer vocational education especially the Two-pathway system, as a result channelling of students to Form three classes was done as per recommendations of the teachers who, in most cases, streamed students using their Form two internal examination results in Mathematics, Science and English.

Some Heads professed ignorance at the policy directing them to implement the Two-pathway as from 2006. This shows clearly that innovations must have an adequate design for implementation, especially dissemination which should imply a producer-consumer relationship. Ministry Officials must ensure that the policy circulars they produce reach schools and also set up some mechanisms to ensure their implementation

\section{Conclusions and Recommendations}

The main argument of this paper is that, inspite of call to reform the Zimbabwean secondary school curriculum and setting up a commission of inquiry into the education system, the curriculum has remained largely academic and therefore irrelevant to the nation's aspirations and developmental needs. The system has continued churning out frustrated students who are unemployed. Students who need social control and re-education in new forms of labour disciplines as jobs in which they used to get their first taste of work have disappeared.

This study also showed that the Nziramasanga Commission made thorough consultations with the general populace and established that the prevailing 
curriculum that was being offered to "O" Level students was no longer viable. It was too academic giving students false hopes of getting white collar jobs that are no longer available hence the recommendation to adopt the two-pathway education system. The Ministry of Education, Sport, Arts and Culture did well in adopting the system although it has been established that its implementation was hindered at the classroom doors. Directors' and Secretary's policy circulars directing the implementation of the Two-Pathway system were a giant step forward but these were given too late as evidenced by the calls that were made in 2010, a decade after the recommendation from the Commission. The implementation strategies, i.e. adoption of continuous assessment in order to properly channel the students into suitable classes/ pathways at "O" Level were also not followed. Pupils were just placed anyhow as teachers and administration wished. The curricula being used does not have the input of commerce and industry people's contribution so that proper skills are imparted to students. The hands-on technique suggested by the Ministry was never adopted as it is difficult to make such arrangements when teachers are teaching for examinations. No time is left to arrange for students to undergo designated periods of attachment so that they have hands-on experience in industry and commerce.

Given this scenario, the study advices that Governments should not take for granted that, since their new ideas are such good ones, they would be widely and rapidly be accepted by schools (Hawes 1979). Reality definers of the day should make sure that there is strict adherence to policy circulars by all stakeholders. Provincial, district and schools inspectors should be financed and be capacitated to supervise the implementations of curriculum reforms. This will give them first hand information on problems being faced by schools and suggest solutions early before the reform is abandoned. The visits will also facilitate fast dissemination of the necessary information and Minute circulars.

There is also need to promptly implement innovations or changes when they are suggested. The moment the developmental process of change takes long to complete, the success of the change is affected and in most cases no proper implementation strategies are followed.

The need to involve all stakeholders, especially from commerce and industry, in the planning process cannot be overemphasized. This will avoid channeling out unproductive, unemployed and unemployable graduates from the school system. All stakeholders are also to be convinced of the necessity to change before they are expected to change.

Subjects to be studied by pupils should not just be imposed on them. All should be allowed to make choices that suit their conditions so that they are receptive to the vocational knowledge they receive.

Proper implementation strategies have also to be followed. Vocationalisation of schools cannot be achieved if Practical subject are taught like academic subjects. 
This can also be caused by lack of resources and Governments, before adopting any changes, should make sure resources, both human and material are made available.

The things that we have to learn before we can do them, we learn by doing them. Men become builders by building and as such teachers are to strive to reproduce adult situations in the classroom in order to prepare pupils for adult life. There is a great need therefore to make students learn by doing by introducing hands-on activities through attaching them to industries.

\section{References}

Dalton, T.H. (1988) The challenges of Curriculum Innovation; A study of ideology and Practice. The Flamer Press London, New York.

Hawes, H. (1979) Curriculum Reality in African Primary Schools. London Longman Ministry of Education, Sports, Arts and Culture Director's Circulars number 2 of 2001

Secretary's circular number 3 of 2002

Secretary's circular number 4 of 2004

Director's circular number 3 of 2006

Director's Policy Circular 77 of 2006

Principal Director 33 of 2010

Director's circular 45 of 2006

Director's circular 9 of 2007

Olivia. P. F. (1992) Developing the Curriculum (3 $3^{\text {rd }}$ Edition) Harper Collins Publishers.

Ornstein, A.C. and Hunkins, F.P. (1993) Curriculum Foundations, Principles and Issues ( $2^{\text {nd }}$ Edition) London Allyn Bacon.

Psacharopolous, G. And Loxley, W. (1985) Diversified Secondary Education and Development- Evidence from Colombia and Tanzania London, The John Hopkins University Press.

Report of the Presidential Commission of Inquiry into Education and Training (1999) Harare

Shiundu, J.S. and Omulando, S.D. (1992) Curriculum Theory and Practice in Kenya; Oxford University Press, Nairobi

The Herald Newspaper 29 July 2010

Woodhall, M. (1981) Education, Work and Unemployment: A Summary Review Canada Ottawa 